\title{
SEISMIC FRAGILITY CURVES FOR LOW AND MEDIUM R.C FRAMED STRUCTURES IN EGYPT
}

\author{
Kandil, K. ${ }^{1}$, Hekal, G. ${ }^{2}$ and Dawod, A. ${ }^{3}$ \\ ${ }^{1}$ Professor of Steel Structures and Bridges Design, Menoufia University, Egypt \\ ${ }^{2}$ Lecturer at Civil Engineering Department, Menoufia University, Egypt \\ ${ }^{3}$ M.Sc. Student, Menoufia University, Egypt

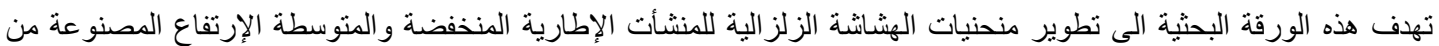

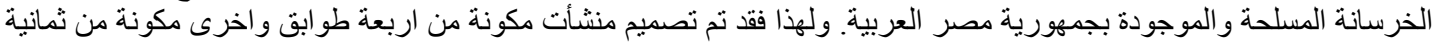 \\ طو ابق طبقا للكود المصرى، حيث تقع هذة المنشأت فى ثلاث مناطق زلز الز الية بمصر (الإسكندرية ـ سفاجا ـ طابا) وذللك لتغطى مجال

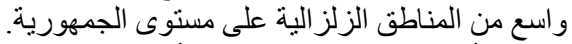

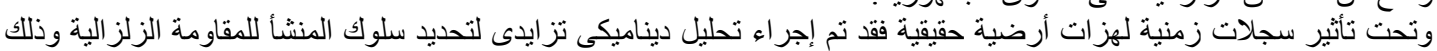

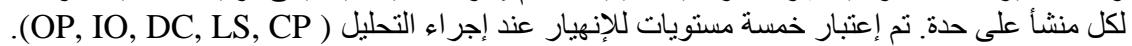

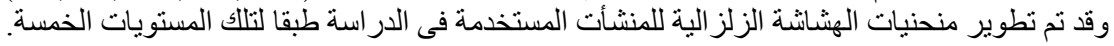

\begin{abstract}
The current research aims at developing seismic fragility curves for reinforced concrete framed structures in Egypt. For that purpose, four and eight-story R.C. frames were designed according to Egyptian Code of Practice. The frames were located in three seismic zones, i.e. Alexandria, Safaga and Taba.

Incremental dynamic analysis was performed under ten ground motions to determine the yielding and collapse capacity of each building. Five performance levels, namely, operational (OP), immediate occupancy (IO), damage control (DC), life safety (LS) and collapse prevention (CP) were considered and monitored in the analysis. Fragility curves were developed for the structural models of the studied frames considering the five selected performance levels.
\end{abstract}

Keywords: Fragility curves; Incremental dynamic analysis; Performance-based design; Lateral load resisting systems; Seismic risk analysis.

\section{Introduction}

Earthquakes may cause extensive losses. Among which, structural damage plays an important role. One of the most important tools in evaluating the seismic damage to structures is the fragility curves. The fragility curves for certain type of building structure are used to represent the probabilities that the structural damages, under various levels of seismic excitation, exceed specified damage states. In other words, each point on the curve represents the probability that the spectral displacement under certain level of ground shaking is larger than the displacement associated with certain damage state (Cherng 2001).

Performance-based earthquake engineering considers the design, evaluation and construction of structures with a seismic performance satisfying the owners and users of these structures (SEAOC 1995, Hamburger1998, Federal Emergency Management
Agency (FEMA) 349, FEMA/EERI 2000, ATC 2002, Vamvatsikos and Cornell 2002). It mainly depends on the fact that the structural performance can be well predicted with sufficient condense so that the engineer and client can select the desired performance level of the structure under different earthquakes, which affect the design and construction of the structure. The life-cycle and importance of the structure as well as the construction costs should be taken into consideration.

When choosing the desired performance level. The performance level is an expression of the maximum desired extent of damage to a structure under specific earthquake design level.

FEMA 273 (1997)/356 (2000) categorized the overall building performance in terms of both the structural and non-structural performance levels.

These performance levels are: 
Operational: The building is immediately suitable for normal use with minimal or no damage to the structural and non-structural components.

Immediate occupancy: The building experiences minimal or no damage to the structural elements and only minor damage to the non-structural components. Immediate occupancy may be possible. However, some clean-up, repair and restoration of service utilities may be necessary before the building can function as before earthquake.

Life safety: The structural and non-structural components are subjected to extensive damage and are in need of repairs before re-occupancy. Repair is possible but may be economically impractical.

Collapse prevention: The structural collapse is prevented with no consideration of non-structural vulnerabilities. The building may create a significant hazard to life safety and be considered as a complete economic loss. Incremental dynamic analysis, IDA, is a parametric analysis method used to estimate structural performance under seismic loads. During IDA, The structural model is subjected to several ground motion records, each scaled to multiple levels of intensity, thus producing response curves parameterized versus intensity level. IDA gives a clear vision about the performance of a certain type of structures under seismic excitations with wide range of intensities (Vamvatsikos and Cornell 2002). Many researchers have developed and used IDA curves in their research. Ibrahim and Elshami (2011) carried out IDA for four and eight-story multistory reinforced concrete (RC) frame buildings in Saudi Arabia. Kircil and Polat (2006) developed IDA curves for mid-rise RC frames in Istanbul. Moridani and Khodayari (2013) have studied the influence of different seismic sources characteristics on the outcomes of IDA. Uriz and Mahin (2004) have used IDA to study seismic performance of concentrically braced steel frames. Mander et al. (2007) developed IDA curves for bridge structures and then the IDA results were integrated into a probabilistic risk analysis procedure. Ibrahim (2009) performed IDA on typical moment-resisting frames located in Egypt. The inter-story drift ratio, i.e. the ratio of story drift between two consecutive floors to story height, is considered as a significant cause that leads to the damage of building structures when subjected to earthquake ground motion. Hence, the desired performance levels are usually interpreted in terms of inter-story drift ratios. Reaching an agreement about the correlation between values of inter-story drift ratios and their corresponding performance levels is not an easy or straight forward task. FEMA 356 provided typical values of inter-story drift ratios for different structural systems for various structural performance levels. For concrete frames, the values are $1 \%, 2 \%$ and $4 \%$ for immediate occupancy (IO), life safety (LS) and collapse prevention (CP), levels, respectively. Based on many references (SEAOC 1995, JSCA 2000, FEMA 450 (2003), International Building Code (IBC) 2003, King and Shelton 2004, Heidebrecht (2004)) and according to local seismic hazard analysis results in Taiwan and based on opinions from the advisory committee of the project for developing the seismic design draft code for buildings in Taiwan using performance-based seismic design methodology, Xue et al. (2008) suggested values of maximum inter-story drift ratio for each performance level for different structural systems. For systems rather than that with masonry shear walls, the values of maximum inter-story drift ratios for performance levels; operational (OP), immediate occupancy (IO), damage control (DC), life safety (LS) and collapse prevention (CP) are tabulated in Table 1. The values are similar to those

Table 1: maximum inter-story drift ratios for different performance levels

(Xue et al. 2008)

\begin{tabular}{||c||c|c|c|c|c||}
\hline Performance level & OP & IO & DC & LS & CP \\
\hline Maximum inter-story drift ratio & 0.005 & 0.010 & 0.015 & 0.02 & 0.025 \\
\hline
\end{tabular}

\section{$\underline{\text { 2. Structural models }}$}

We are going to discuss the behavior of two types of structures under lateral loads in three seismic zones (ALEXANDRIA as zone No.2 \& SAFAGA as zone No.4 and TABA as zone NO.5B) so that it covers all over Egypt.

- The 1st type is a 2D reinforced concrete frame (four storey frame)

- The 2nd type is a 2D reinforced concrete frame (eight storey frame)
I.e. these two types are designed 3 times to be built in the 3 zones (ALEXANDRIA, SAFAGA and TABA). Each frame is three bays frame, bay length is $3 \mathrm{~m}$ and story height is $3 \mathrm{~m}$.

The structural systems were designed according to the Egyptian Building Code the compressive strength of concrete is $250 \mathrm{~kg} / \mathrm{cm}^{2}$, the yielding stress of reinforcing steel is $3600 \mathrm{~kg} / \mathrm{cm}^{2}$, the soil class was assumed $\mathrm{C}$, which is medium soil. The frames are 
classified as low hazard buildings, with importance factor $\mathrm{I}=1$

Figures 1 to 6 show the structural system details of the frames under study.

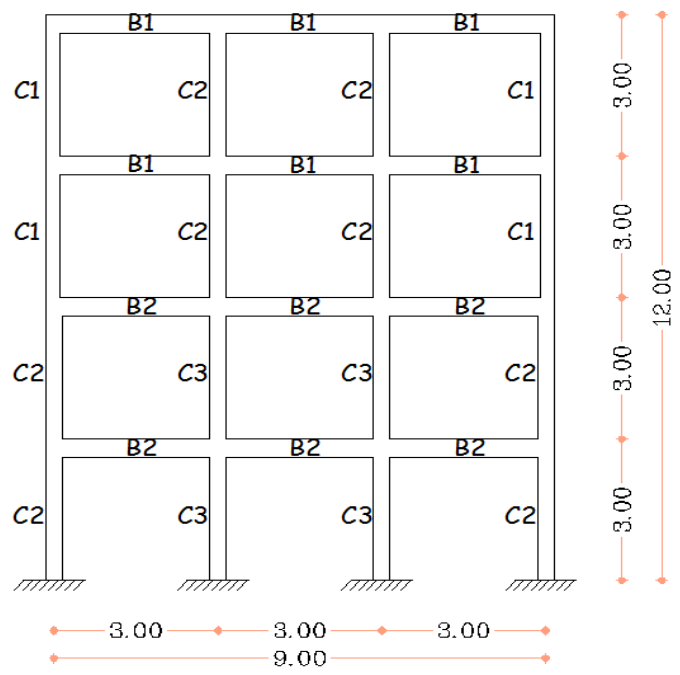

Figure 1: Four storey frame in ALEX. (M1)
Tables 2 and 3 show the R.C sections for columns and beams respectively.

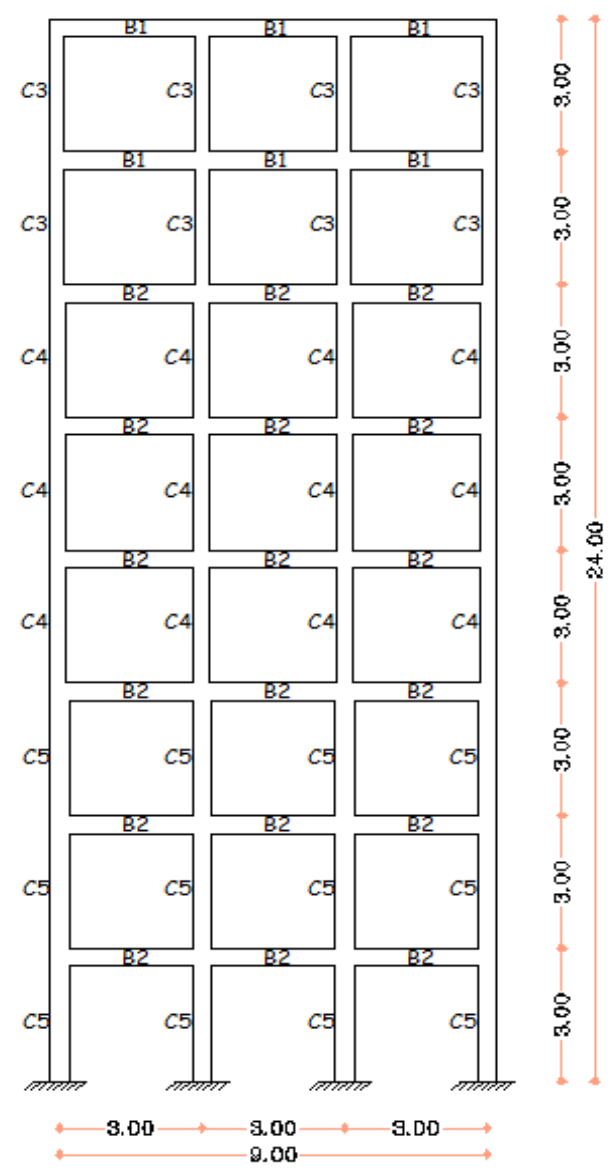

Figure 2: Eight storey frame in ALEX. (M2) 


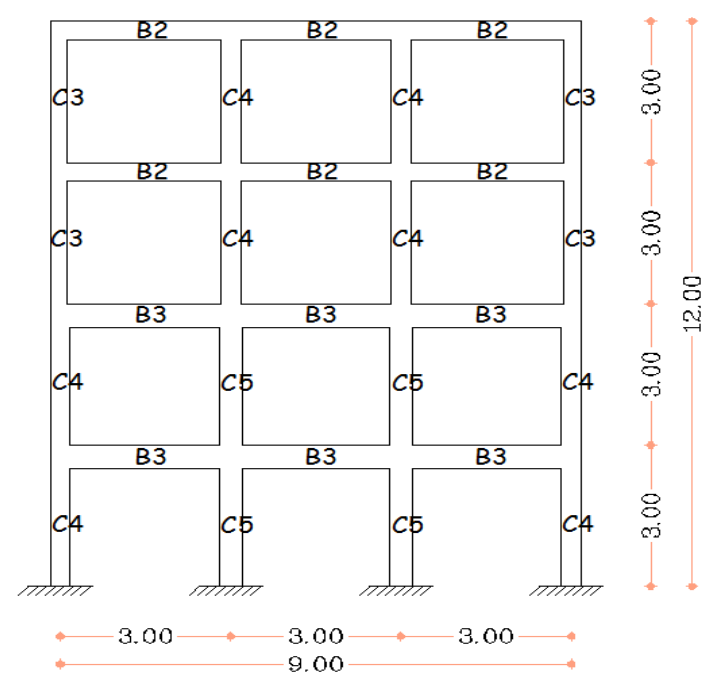

Figure 3: Four storey frame in SAFAGA (M3)

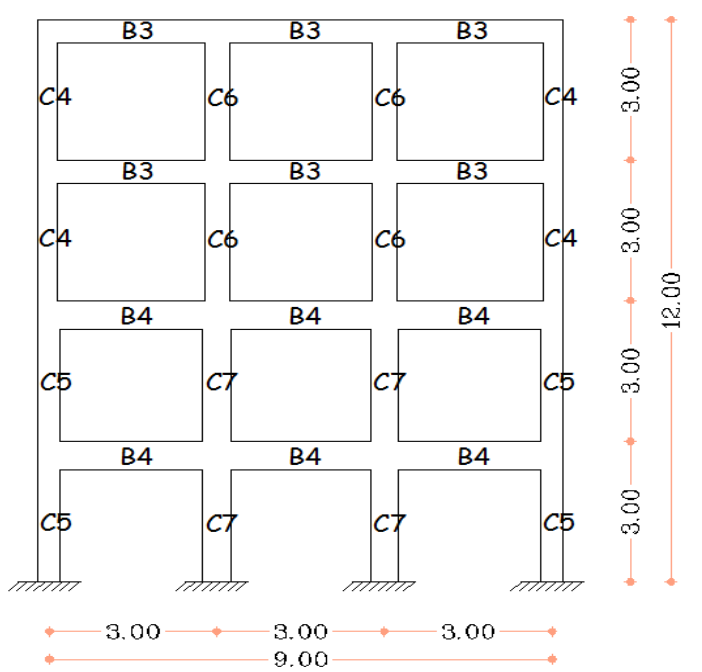

Figure 5: Four storey frame in TABA (M5)

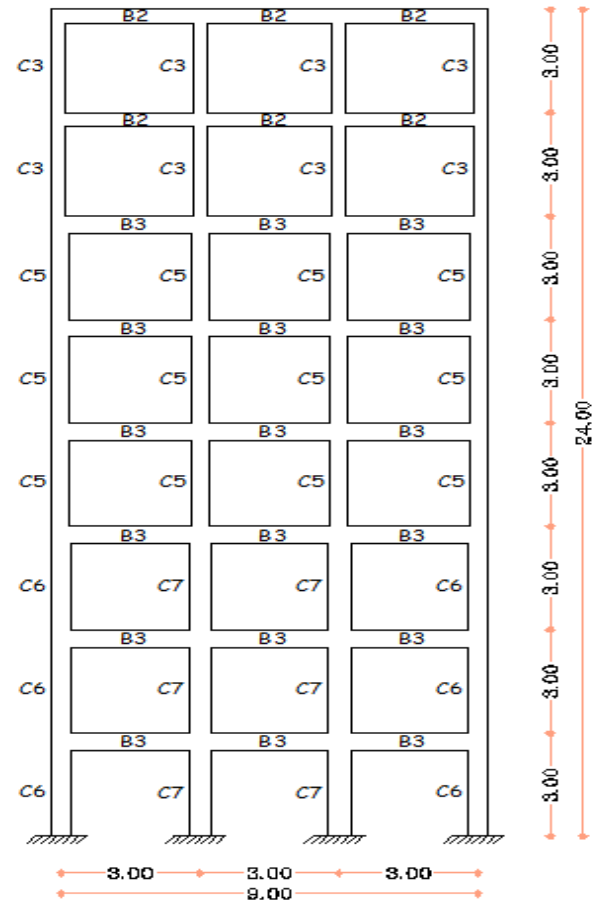

Figure 4: Eight storey frame in SAFAGA (M4)

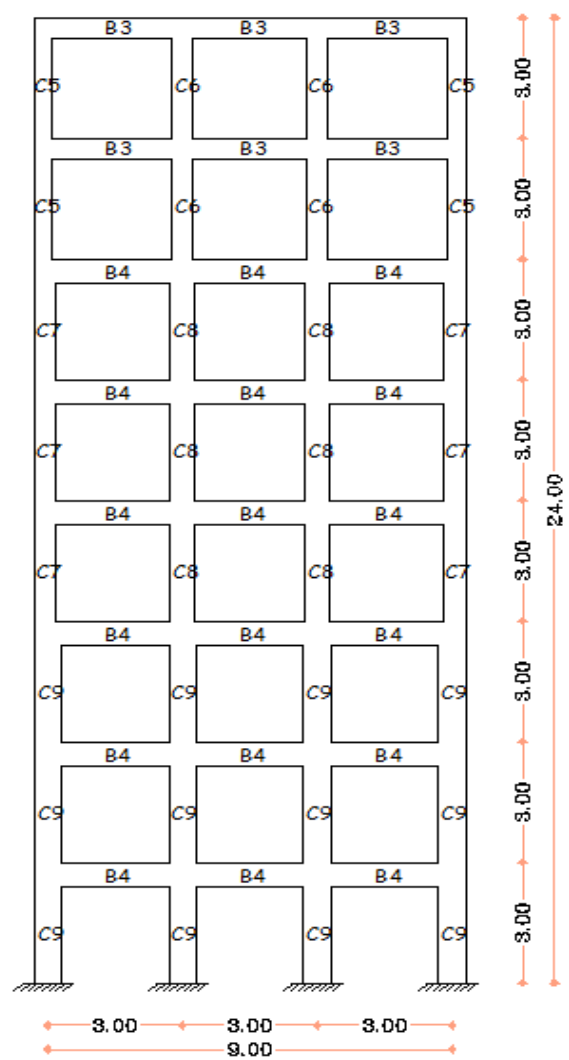

Figure 6: Eight storey frame in TABA (M6)

Table 2: Columns cross sections 
Kandil, K., Hekal, G. and Dawod, A. "SEISMIC FRAGILITY CURVES FOR LOW AND MED...."

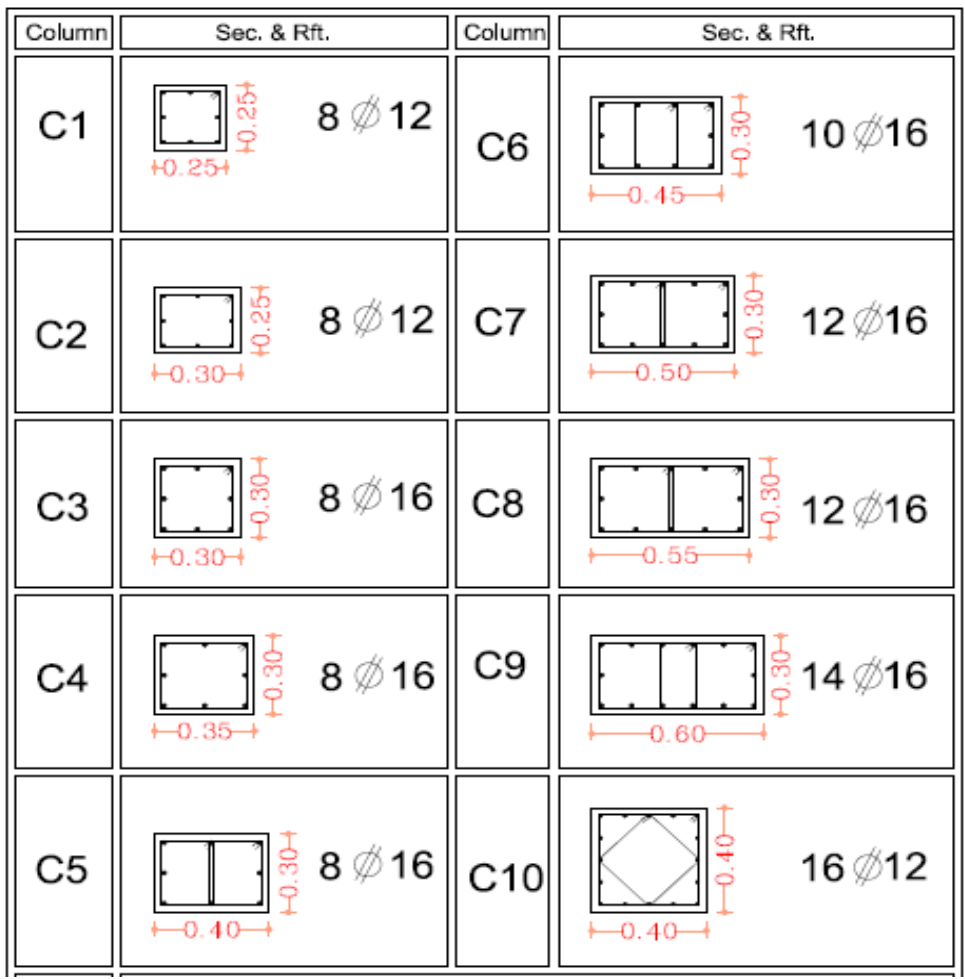

Table 3: Beams cross sections

\begin{tabular}{|c|c|c|c|c|}
\hline Beam & Sec. \& Rft. & Beam & Sec. 8 & Rft. \\
\hline B1 & 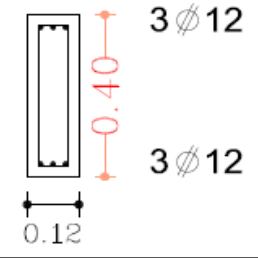 & \multirow[t]{2}{*}{ B4 } & 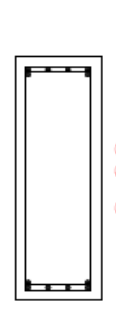 & \multirow[t]{2}{*}{$\begin{array}{l}6 \not \supset 16 \\
6 \not D 16\end{array}$} \\
\hline \multirow{2}{*}{ B2 } & $\cdots b^{4 \not 12}$ & & 10.20 & \\
\hline & L...20 & \multirow[b]{2}{*}{ B5 } & 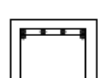 & $6 \not \varnothing 16$ \\
\hline B3 & 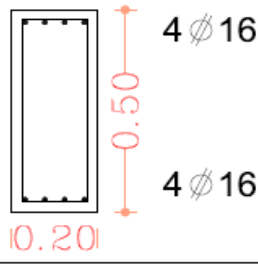 & & $\frac{\int_{0} \cdot \mid}{10.201}$ & $2 \not \supset 12$ \\
\hline
\end{tabular}




\section{Incremental dynamic analysis}

An appropriate set of ground motions is required to perform IDA. As suggested by several seismic codes (e.g. Uniform Building Code (UBC) 1997 and ENV1998-1, 2005) and by researchers (e.g. Bommer et al. (2003), a minimum of seven ground motions should be used to describe the behavior of a building. Rota et al. (2010) used seven ground motions to perform IDA and develop fragility curves for threestory masonry building located in Benevento, Italy. Ten ground motions have been used in the current study. The characteristics of such earthquakes are tabulated in Table 4. The six studied frames were subjected to the selected ten ground motions using SeismoStruct.

Using SeismoStruct software, the nonlinear time history analysis was conducted on each structure using a certain ground motion with the peak ground acceleration, PGA scaled incrementally up to $1.0 \mathrm{~g}$ using a step of $0.1 \mathrm{~g}$. The maximum inter story drift ratio was calculated for each $\mathrm{PGA}$, and this represents a point on the IDA curve. The points of this drift ratio resulting from the various PGA values form the full IDA curve for a specific ground motion. The procedure was repeated for all 10 ground motions used in this paper. The full set of the IDA curves from these 10 ground motions characterize the seismic response of a specific structural model. The IDA curves for the structural models are presented in Figures 7 to 12 .

It was calculated as the number of occurrence among the ground motions that exceeded certain performance level at each PGA value. Then the probability of exceeding this damage state was calculated. Mean and standard deviation, $\mu$ and $\sigma$, of the natural logarithm of PGA at which each structure reaches the threshold of a specific damage state or performance level were calculated. These values are tabulated in Table 5 and were used in developing the fragility curves presented below.

Table 4: Details of ground motions

\begin{tabular}{|c|c|c|c|c|c|}
\hline No. & Ground motion & Station & Date & $\begin{array}{c}\text { PGA } \\
(\mathbf{g})\end{array}$ & $\begin{array}{c}\text { Duration, } \\
\text { sec. }\end{array}$ \\
\hline $\mathbf{1}$ & CHICHI & TAIWAN & Sep, 20,1999 & 0.36 & 50 \\
\hline $\mathbf{2}$ & FRIULI & ITALY & May,06,1976 & 0.35 & 36 \\
\hline $\mathbf{3}$ & HOLLISTER & USA & Apr, 09,1961 & 0.2 & 40 \\
\hline $\mathbf{4}$ & IMPERIAL VALLEY & USA & Oct, 15,1979 & 0.32 & 40 \\
\hline $\mathbf{5}$ & KOBE & JAPAN & Jan, 16,1995 & 0.34 & 40 \\
\hline $\mathbf{6}$ & KOCAELI & TURKEY & Aug, 17,1999 & 0.35 & 35 \\
\hline $\mathbf{7}$ & LANDERS & USA & Jun, 28,1992 & 0.64 & 48 \\
\hline $\mathbf{8}$ & LOMA, PRIETTA & USA & Oct, 18,1989 & 0.36 & 40 \\
\hline $\mathbf{9}$ & NORTHRIDGE & USA & Jan, 17,1994 & 0.57 & 40 \\
\hline $\mathbf{1 0}$ & TRNIDAD & USA & Aug, 24,1983 & 0.19 & 21 \\
\hline
\end{tabular}

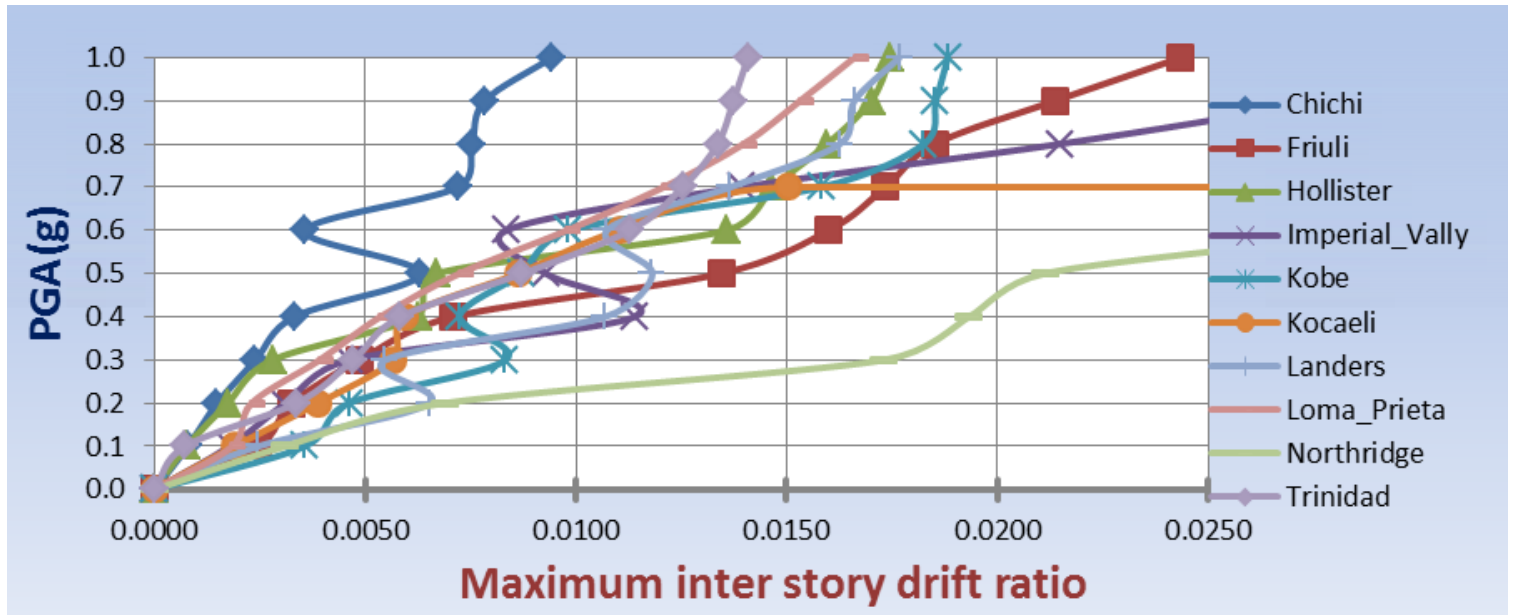

Figure 7: IDA curves for the 4 storey frame in ALEX 


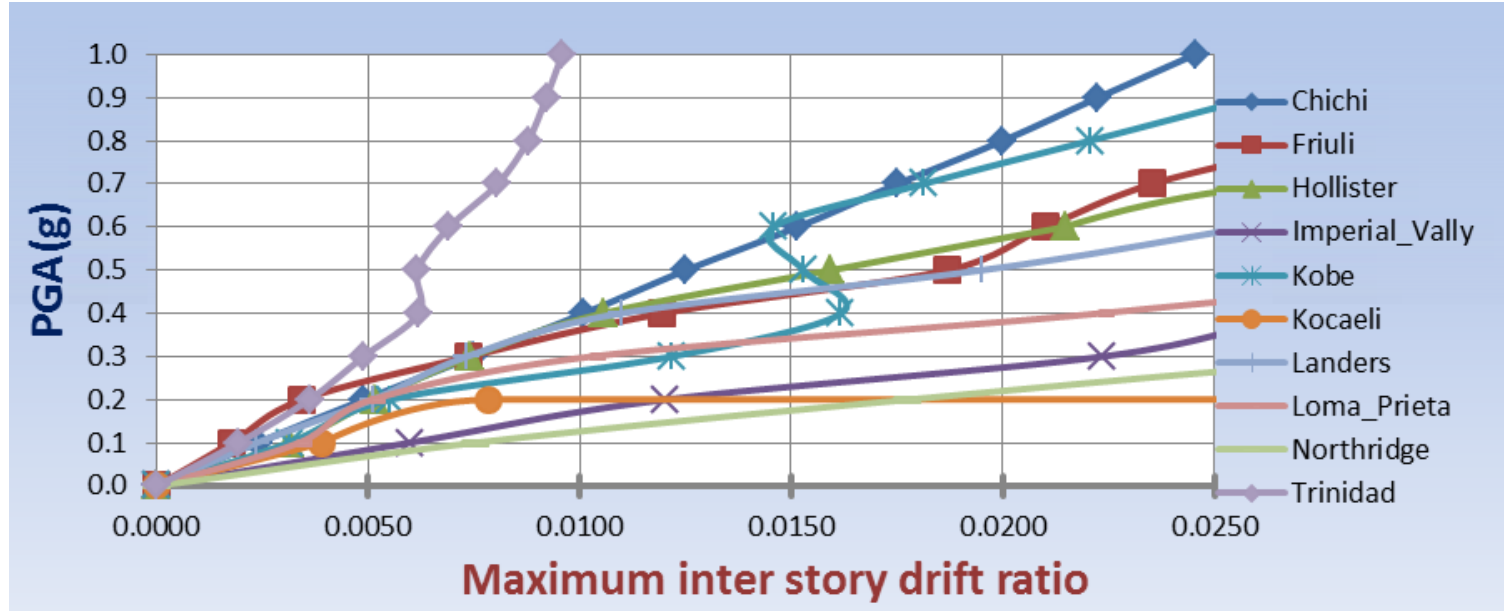

Figure 8: IDA curves for the 8 storey frame in ALEX

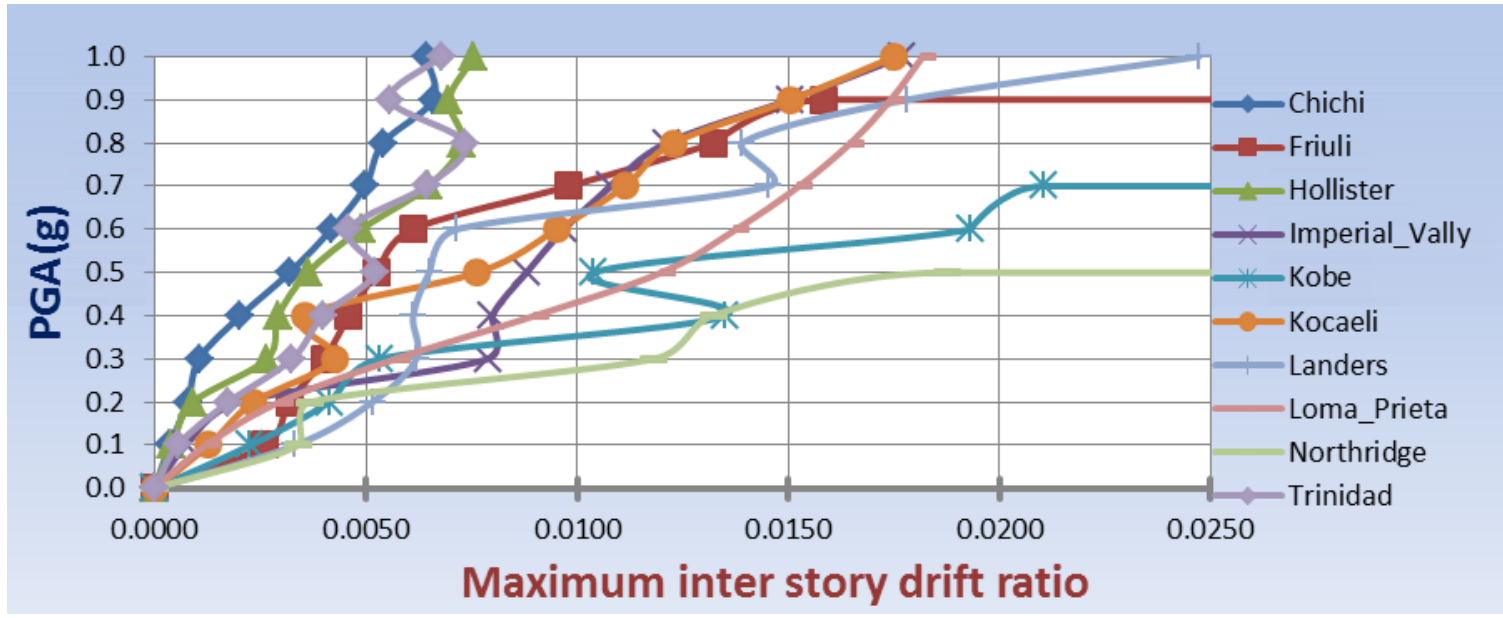

Figure 9: IDA curves for the 4 storey frame in SAFAGA

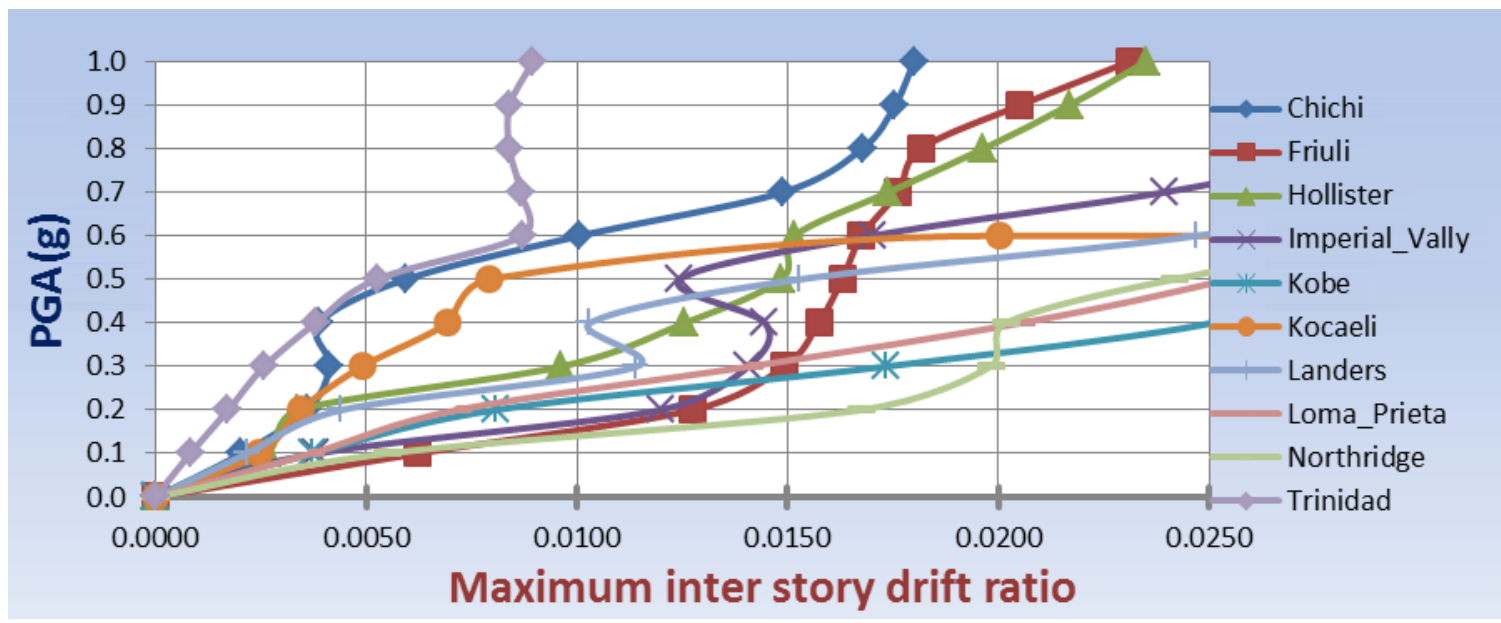

Figure 10: IDA curves for the $\underline{8 \text { storey frame in SAFAGA }}$ 


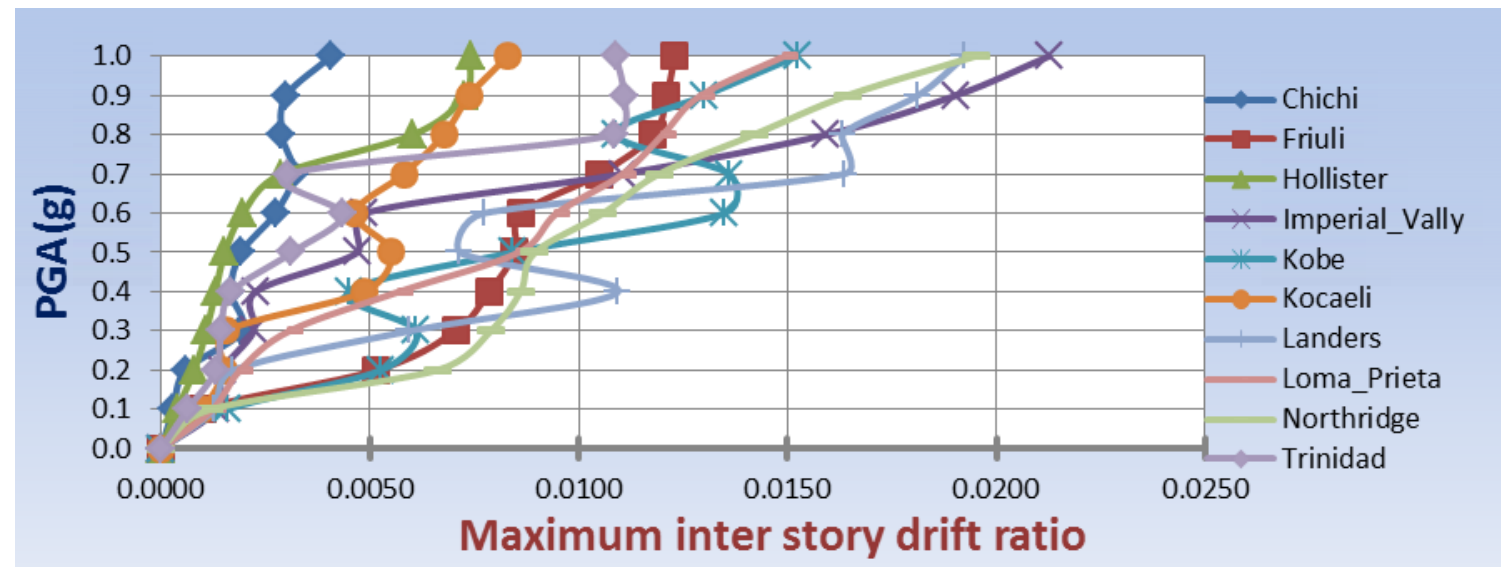

Figure 11: IDA curves for the 4 storey frame in TABA

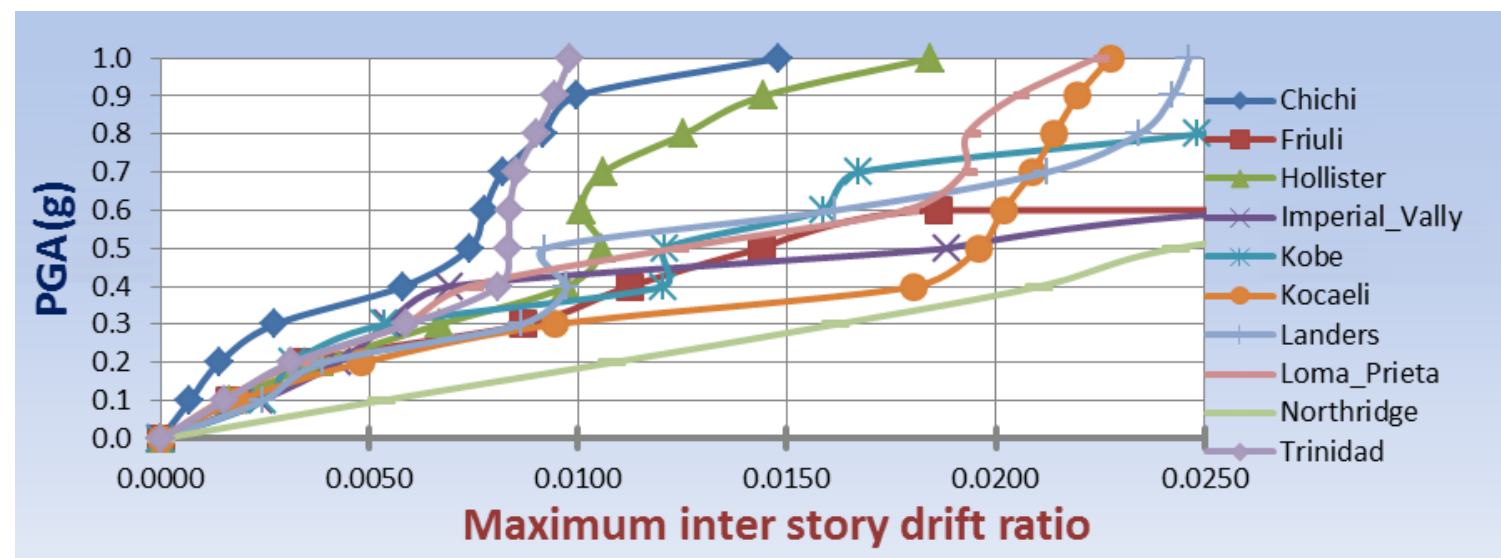

Figure 12: IDA curves for the $\underline{8 \text { storey frame in TABA }}$

As can be noted from all curves, IDA curve differs from one ground motion to another leading to a wide range of response for each structure. The common property shared by all curves is that data points create a linear region at lower scale factors. By increasing scale factor the curves begin to bend meaning that the structure begins to yield. The best seismic performance seems to be obtained for the structures which located in TABA.

\section{$\underline{\text { 4. Fragility curves }}$}

Fragility curves are log-normal functions which express the probability of reaching or exceeding a specific damage state. They can be developed in terms of a seismic parameter, such as spectral acceleration, spectral displacement, peak ground velocity and PGA. Since PGA was the parameter used in developing the IDA in this research and also in a previous one (Ibrahim and El-Shami 2010), the PGA was selected to be the corresponding parameter in developing the fragility curves. The cumulative
For better assessment of structural performance, seismic fragility curves for each structure needs to be extracted at the five performance levels tabulated in Table 1.

The vertical gridlines on each curve at maximum inter-story drift ratio of $0.005,0.01,0.015,0.02$ and 0.025 represent performance level of OP, IO,DC, LS and $\mathrm{CP}$, respectively.

distribution functions was calculated by dividing the number of data points that reached or exceeded a particular damage state by the number of data points of the whole sample (Shinozuka et al. 2003). The conditional probability of a structure to reach or exceed a specific damage state, $\mathrm{D}$, given the PGA, is defined by:

$$
\mathrm{P}[\mathrm{D} / \mathrm{PGA}]=\Phi((\ln (\mathrm{PGA})-\mu) / \sigma)
$$

where $\phi$ is the standard normal cumulative distribution function $\mu$ and $\sigma$ are the mean value and 
standard deviation of the natural logarithm of PGA at which the building reach the threshold of a specific damage state or performance level, D. Log-normal functions with two parameters $(\mu$ and $\sigma$ ) were fitted for different performance levels: OP, IO, DC, LS and $\mathrm{CP}$, associated with the frames under study.

Table 5: Parameters of log-normal distributions for fitting data for the studied frames

\begin{tabular}{|c||c|c||c|c||c|c||c|c||c||c||}
\hline \multirow{2}{*}{ Frame } & \multicolumn{2}{|c||}{ OP } & \multicolumn{2}{c||}{ IO } & \multicolumn{2}{c||}{ DC } & \multicolumn{2}{|c||}{ LS } & \multicolumn{2}{|c|}{ CP } \\
\cline { 2 - 12 } & $\mu$ & $\sigma$ & $\mu$ & $\sigma$ & $\mu$ & $\sigma$ & $\mu$ & $\sigma$ & $\mu$ & $\sigma$ \\
\hline \hline M1 & 0.22 & 0.45 & 0.47 & 0.47 & 0.68 & 0.42 & 1.13 & 0.62 & 1.16 & 0.52 \\
\hline M2 & 0.13 & 0.31 & 0.26 & 0.71 & 0.36 & 0.60 & 0.45 & 0.60 & 0.52 & 0.66 \\
\hline M3 & 0.32 & 0.44 & 0.63 & 0.56 & 0.83 & 0.39 & 1.16 & 0.52 & 1.26 & 0.59 \\
\hline M4 & 0.15 & 0.68 & 0.29 & 0.74 & 0.40 & 0.58 & 0.59 & 0.59 & 0.72 & 0.54 \\
\hline M5 & 0.43 & 0.65 & 0.70 & 0.44 & 1.00 & 0.24 & 1.06 & 0.11 & 1.26 & 0.21 \\
\hline M6 & 0.21 & 0.37 & 0.32 & 0.83 & 0.58 & 0.50 & 0.73 & 0.42 & 0.99 & 0.54 \\
\hline
\end{tabular}

The input data points and the log-normal function fitted for different performance levels occurred in the frame [M1] are shown in Figure 13. Table 6 shows the probability of exceeding performance levels at certain PGA for the frame [M1]. Figure 14 and 19 show the whole set of fragility curves for frames under study.

Table 6: The probability of exceeding performance levels at certain PGA for the frame [M1]

\begin{tabular}{|c|c|c|c|c|c|}
\hline PGA $(\mathrm{g})$ & OP & IO & DC & LS & CP \\
\hline 0.0 & 0.00 & 0.00 & 0.00 & 0.00 & 0.00 \\
\hline 0.1 & 0.04 & 0.00 & 0.00 & 0.00 & 0.00 \\
\hline 0.2 & 0.41 & 0.03 & 0.00 & 0.00 & 0.00 \\
\hline 0.3 & 0.75 & 0.16 & 0.03 & 0.02 & 0.01 \\
\hline 0.4 & 0.91 & 0.36 & 0.10 & 0.05 & 0.03 \\
\hline 0.5 & 0.97 & 0.55 & 0.24 & 0.09 & 0.06 \\
\hline 0.6 & 0.99 & 0.69 & 0.39 & 0.15 & 0.11 \\
\hline 0.7 & 0.99 & 0.80 & 0.53 & 0.22 & 0.17 \\
\hline 0.8 & 1.00 & 0.87 & 0.66 & 0.29 & 0.24 \\
\hline 0.9 & 1.00 & 0.92 & 0.75 & 0.36 & 0.31 \\
\hline 1.0 & 1.00 & 0.95 & 0.83 & 0.42 & 0.37 \\
\hline
\end{tabular}

From these results, it's clear to us that when the frame in case [M1]:

Exposed to weak ground motion with PGA $=0.2 \mathrm{~g}$, then the probability of exceeding the OP performance level is equal to $41 \%$ \& the probability of exceeding the DC performance level is equal to $0 \%$. When it exposed to the ground motion with $\mathrm{PGA}=0.4 \mathrm{~g}$, then the probability of exceeding the OP performance level is equal to $91 \%$ \& the probability of exceeding the DC performance level is equal to $10 \%$ the probability of exceeding the $\mathrm{CP}$ performance level is equal to $3 \%$. When it exposed to the ground motion with $\mathrm{PGA}=0.6 \mathrm{~g}$, then the probability of exceeding the OP performance level is equal to $99 \%$ \& the probability of exceeding the DC performance level is equal to $39 \%$ the probability of exceeding the CP performance level is equal to $11 \%$. When it exposed to strong ground motion with $\mathrm{PGA}=0.8 \mathrm{~g}$, then the probability of exceeding the OP performance level is equal to $100 \%$ \& the probability of exceeding the DC performance level is equal to $66 \%$ the probability of exceeding the CP performance level is equal to $24 \%$. 
When it exposed to very strong ground motion with $\mathrm{PGA}=1.0 \mathrm{~g}$, then the probability of exceeding the OP performance level is equal to $100 \%$ \& the probability of exceeding the DC performance level is equal to

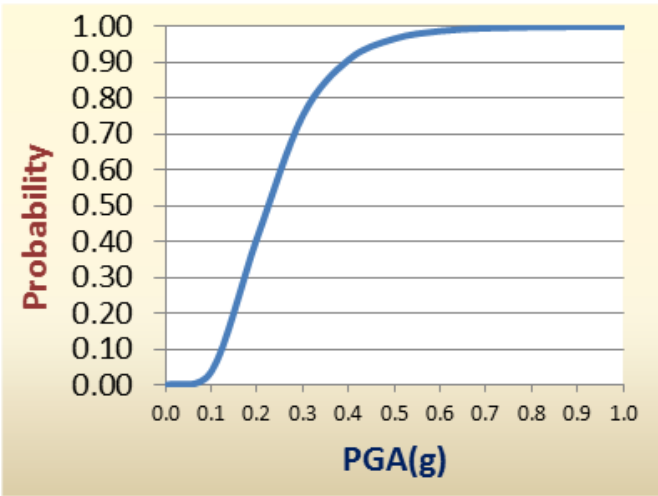

OP

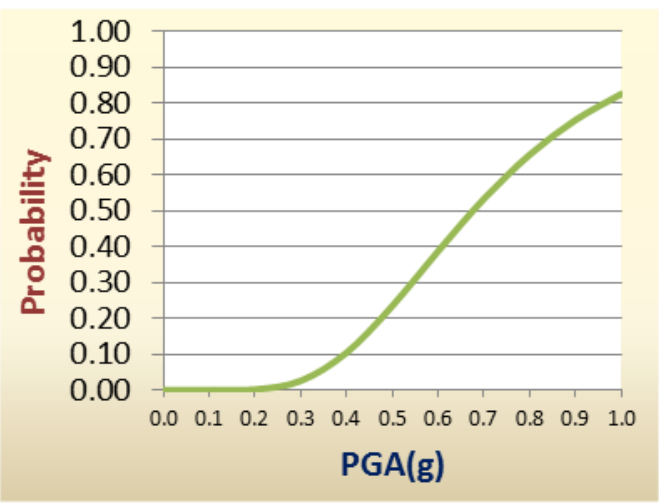

DC
$83 \%$ the probability of exceeding the CP performance level is equal to $37 \%$.

$\mathrm{SO}$, now we can notice that the fragility curves are very useful tools for expectation the extent of probable damage.

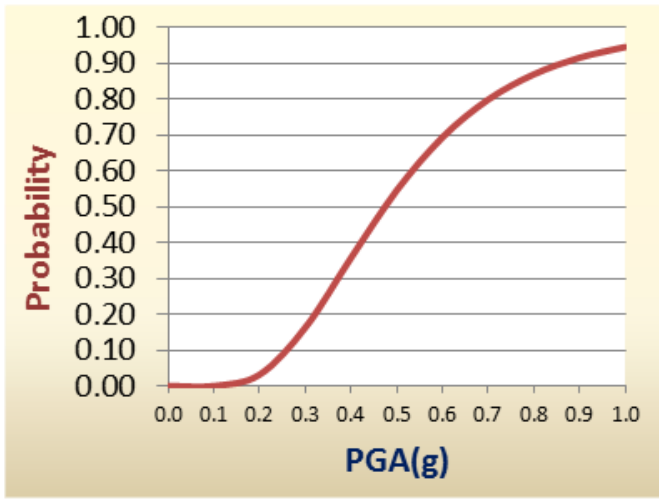

IO

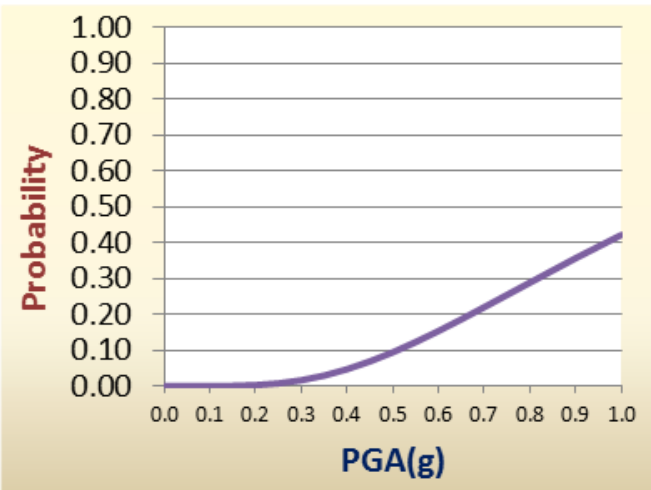

LS

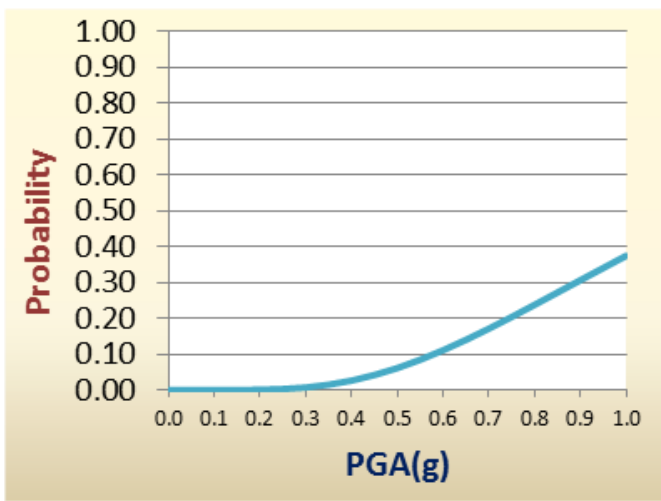

$\mathbf{C P}$

Figure 13. Fitted curves for the M1 frame for different performance levels 
Kandil, K., Hekal, G. and Dawod, A. " SEISMIC FRAGILITY CURVES FOR LOW AND MED...."

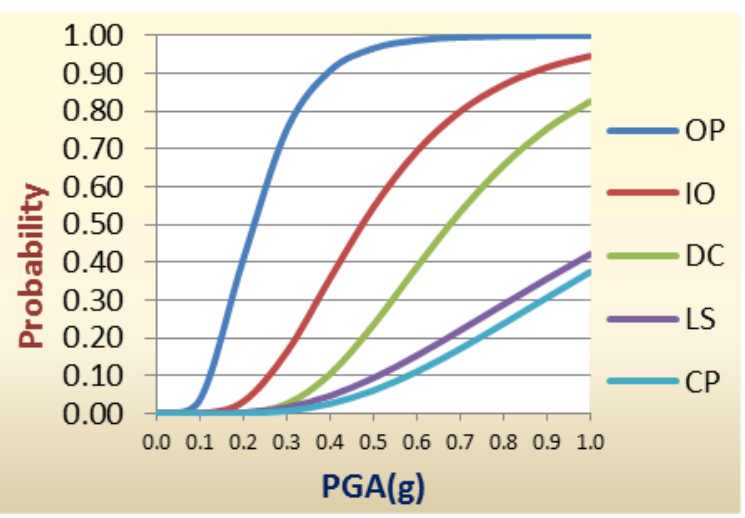

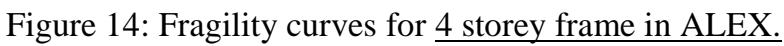

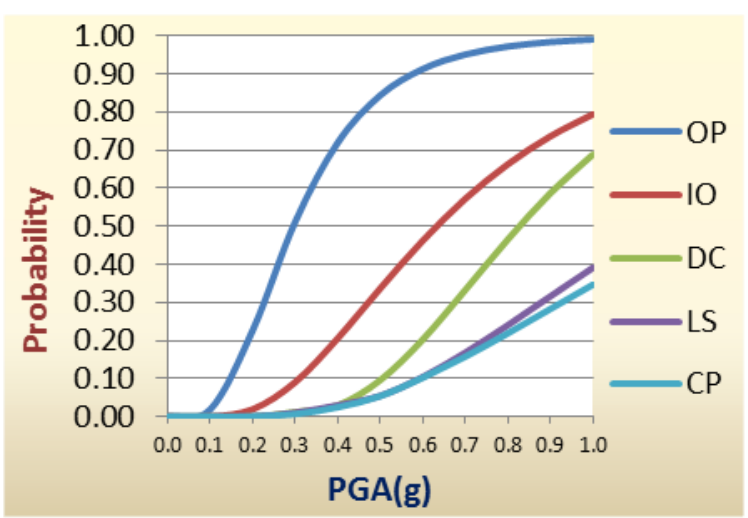

Figure 16: Fragility curves for $\underline{4 \text { storey frame in }}$ $\underline{\text { SAFAGA }}$

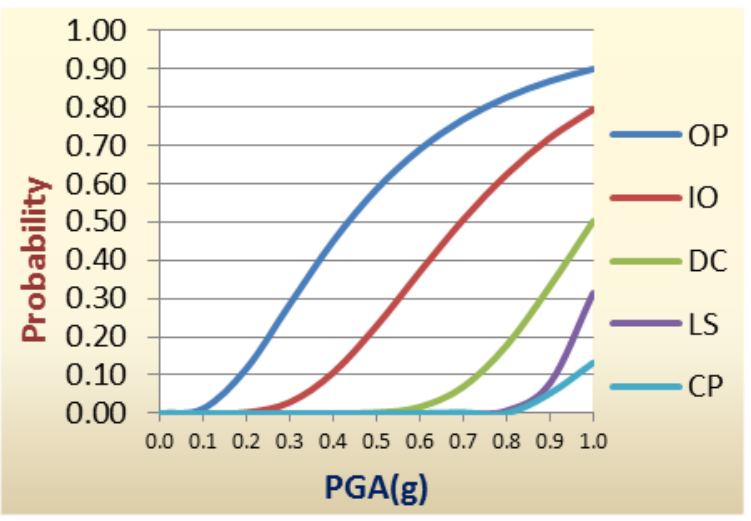

Figure 18: Fragility curves for $\underline{4 \text { storey frame in TABA }}$

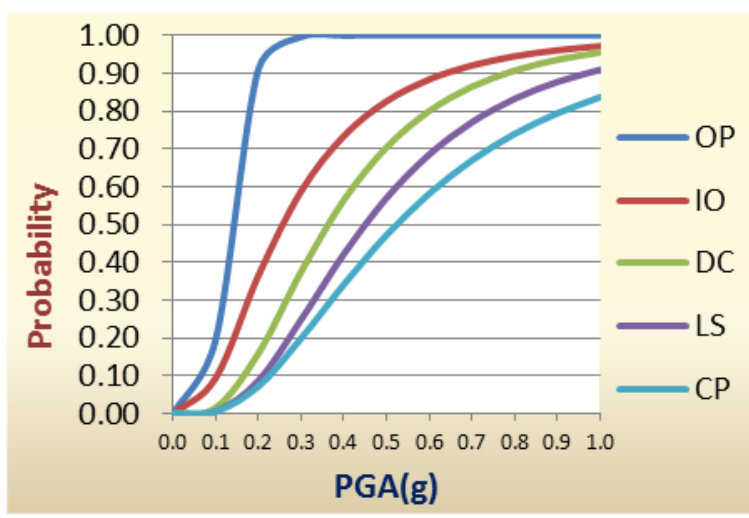

Figure 15: Fragility curves for $\underline{8 \text { storey frame in ALEX. }}$

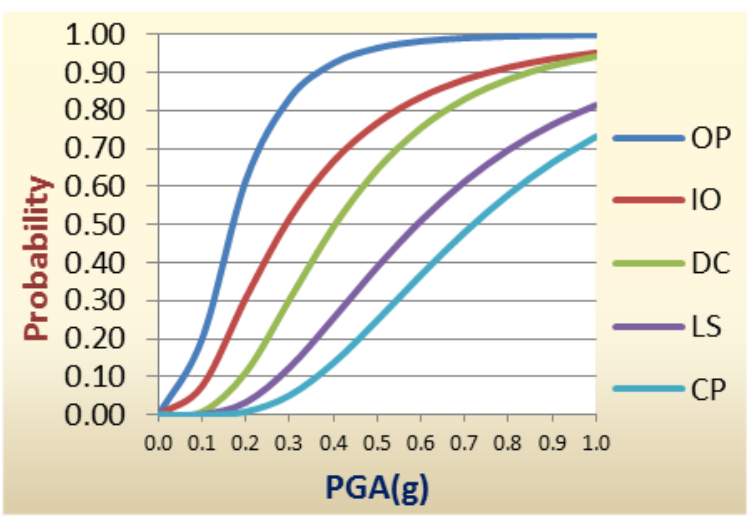

Figure 17: Fragility curves for $\underline{8 \text { storey frame in }}$ SAFAGA

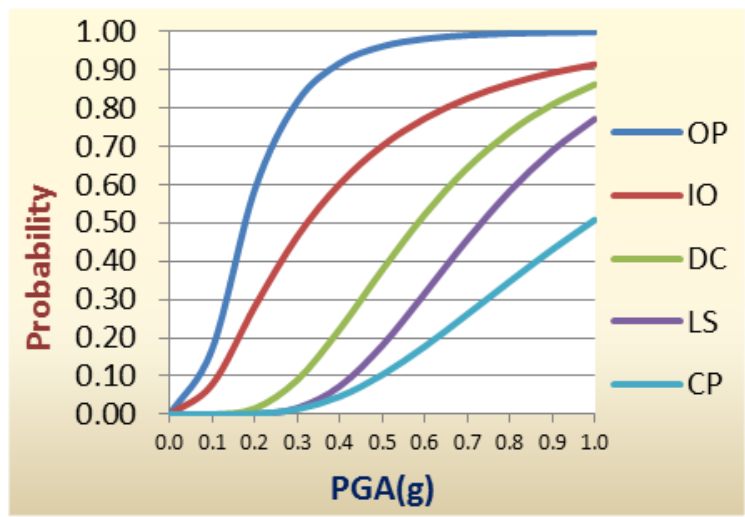

Figure 19: Fragility curves for $\underline{8 \text { storey frame in TABA }}$ 
From these fragility curves, it's shown that:

When exposed to relatively weak ground motions, PGA $=0.2 \mathrm{~g}$, the probability of reaching or exceeding the operational limit is about $41 \%, 23 \%$ and $12 \%$ for the four storey structures in Alexandria, Safaga and Taba respectively; However, the probability of reaching or exceeding the collapse damage limit is about $0.0 \%$ for the four storey structures in Alexandria, Safaga and Taba.

When exposed to relatively strong ground motions, PGA $=0.6 \mathrm{~g}$, the probability of reaching or exceeding the operational limit is about $99 \%, 91 \%$ and $69 \%$ for the four storey structures in Alexandria, Safaga and Taba respectively; However, the probability of reaching or exceeding the collapse damage limit is about $11 \%, 10 \%$ and $0.0 \%$ for the four stories structures in Alexandria, Safaga and Taba respectively;

When exposed to relatively weak ground motions, PGA $=0.2 \mathrm{~g}$, the probability of reaching or exceeding the operational limit is about $91 \%, 62 \%$ and $59 \%$ for the eight storey structures in Alexandria, Safaga and Taba respectively; However, the probability of

\section{Summary and conclusions}

In this study, seismic fragility curves for four- and eight-storey RC moment-resisting frames are presented. These frames were designed according to Egyptian building code for three cities: Alex, Safaga and Taba, to cover wide range of mapped spectral acceleration values in Egypt. The compressive strength of concrete is $250 \mathrm{~kg} / \mathrm{cm}^{2}$, the yielding stress of reinforcing steel is $3600 \mathrm{~kg} / \mathrm{cm}^{2}$, the soil class was assumed $\mathrm{C}$, which is medium soil. The frames are classified as low hazard buildings, with importance factor I=1. IDA was conducted by using 'SeismoStruct' software under 10 ground motions. IDA curves showed wide range of behavior with large variation from record to record. Different structural and non-structural performance levels are considered. These levels are operational (OP),

\section{References}

1- ATC, 2002. Development of performancebased earthquake design guidelines. Redwood City: ATC-58.

2- Bommer J.J., Acevedo, A.B., and Douglas, J., 2003. The selection and scaling of real earthquake accelerograms for use in seismic design and assessment. In: Proceeding of ACI international conference on seismic bridge design and retrofit. La Jolla, CA: American Concrete Institute. reaching or exceeding the collapse damage limit is about $07 \%, 01 \%$ and $0.0 \%$ for the eight storey structures in Alexandria, Safaga and Taba respectively;

When exposed to relatively strong ground motions, PGA $=0.6 \mathrm{~g}$, the probability of reaching or exceeding the operational limit is about $100 \%, 98 \%$ and $98 \%$ for the eight storey structures in Alexandria, Safaga and Taba respectively; However, the probability of reaching or exceeding the collapse damage limit is about $58 \%, 37 \%$ and $18 \%$ for the eight stories structures in Alexandria, Safaga and Taba respectively;

Model No.2 (Eight storey 2D-frame in Alex), the performance under ground motions was not satisfactory. The fully operational limit was obtained at low values of PGA values.

Models No.5 and No.6 (Four, Eight storey 2D-frames in Taba), the performance underground motions was satisfactory. The collapse prevention limit was obtained at high values of PGA values.

immediate occupancy (IO), damage control (DC), life safety (LS) and collapse prevention (CP). Good seismic performance is obtained for different structural models under different ground motions. Better seismic performance is obtained in structures designed in Taba city compared to Safaga and Alexandria for the four- and eight-storey structures. The fragility curves were developed based on the results of IDA and after specifying a value for interstory drift ratio corresponding to each performance level.

Fragility curves are very useful tools for studying the behavior of certain structure to seismic resistance, judgment on it and expecting the structural system which gives best efficiency for seismic resistance.

3- Cherng R., 2001. Preliminary Study on the Fragility Curves for Steel Structures in Taipei, earthquake engineering and engineering seismology, Volume 3, Number 1, pp. 35-42

4- ENV 1998-1: 2005. Eurocode8: Design of Structures for Earthquake Resistance - Part 1: General rules, seismic actions and rules for buildings, Code of Practice, London. 
5- Federal Emergency Management Agency (FEMA) 273, 1997. NEHRP guidelines for the seismic rehabilitation of buildings. Washington DC: Federal Emergency Management Agency.

6- Federal Emergency Management Agency (FEMA) 349, FEMA/EERI, 2000 Action plan for performance - based seismic design. Washington DC: Federal Emergency Management Agency.

7- Federal Emergency Management Agency (FEMA) 356, 2000. Pre-standard and commentary for the seismic rehabilitation of buildings. Washington DC: Federal Emergency Management Agency.

8- Federal Emergency Management Agency (FEMA) 450, 2003. (NEHRP recommended provisions for seismic regulations for new buildings and other structures, Part 1: provisions). Washington DC: Federal Emergency Management Agency.

9- Hamburger, R.O., 1998. Performance-based analysis and design procedure for moment resisting steel frames .Back ground Document, SAC Steel Project.

10- Heidebrecht, A., 2004. Code development issues arising from the preparation of the seismic provisions of the national building Code of Canada. 13WCEE, Vancouver, Canada:3218-3228.

11- Ibrahim, Y. and El-Shami, M., 2011. Seismic fragility curves for mid-rise reinforced concrete frames in Kingdom of Saudi Arabia, he IES Journal Part A: Civil \& Structural Engineering, Vol. 4, No. 4, 213-223

12- Ibrahim, Y.E., 2009. Performance limits of mid-rise moment-resisting framed structures in low seismicity areas. In The 11th Arab structural engineering conference, 2527October. Dhahran, Saudi Arabia: KFUPM.

13- International Building Code (IBC), 2003. CA, USA: International Code Council, Delmar Cengage Learning.

14- Japan Structural Consultants Association, JSCA, 2000.Structural design by response control methods, Shoko-kusha Publishing Co. Ltd., Tokyo, Japan [in Japanese].

15- King, A. and Shelton, R., 2004. New Zealand advances in performance-based seismic design. 13WCEE, Vancouver, Canada: 13-25.

16- Kircil, M. and Polate, Z., 2006. Fragility analysis of mid-rise R/C frame buildings, Engineering Structures 28, 1335-1345
17- Madas, P., 1993. Advanced modeling of composite frames subjected to earthquake loading. Thesis (PhD). London, UK: Imperial College, University of London.

18- Mander, J.B., et al., 2007. Incremental dynamic analysis applied to seismic financial risk assessment of bridges. Engineering Structures, 29 (10), 2662-2672.

19- Mander, J.B., Priestley, M.J.N., and Park, R., 1988.Theoretical stress-strain model for confined concrete. Journal of Structural Engineering, 114 (8), 1804-1826.

20- Moridani, K. and Khodayari, R., 2013. Seismic Performance Assessment Uses Incremental Dynamic Analysis, Journal of Basic and Applied Scientific Research, 3(8)757-764

21- Rota, M., Penna, A., and Magnes, G., 2010. A methodology for deriving analytical fragility curves for masonry buildings based on stochastic nonlinear analyses. Engineering Structures, 32, 1312-1323.

22- SeismoStruct Ver. 5.0.4, 2010. SeismoSoft, earthquake engineering software solutions [online]. Italy. Available from: www.seismosoft.com [Accessed 10 August 2011].

23- Shome, N. and Cornell, C.A., 1999. Probabilistic seismic demand analysis of nonlinear structures. Dissertation( $\mathrm{PhD})$, Stanford: Stanford University.

24- Structural Engineers Association of California, SEAOC, Vision 2000, 1995. Performance based seismic engineering of buildings. Sacramento, CA: Vision 2000 Committee.

25- Uriz,P. and Mahin, S., 2004. Seismic Performance Assessment of Concentrically Braced Steel Frames, 13th World Conference on Earthquake Engineering , Vancouver, B.C., Canada

26- Vamvatsikos, D. and Cornell, C.A., 2002. Incremental dynamic analysis. Journal of Earthquake Engineering and Structural Dynamics, 31 (3), 491-514.

27- Xue, Q., et al., 2008. The draft code for performance-based seismic design of buildings in Taiwan. Engineering Structures, 30, 1535-1547 